\title{
Wind Fields over Lake Biwa and Their Effect on Water Circulation
}

\author{
Shuichi Endoh, Miwa Watanabe, Hiroki Nagata, Fumihito Maruo, Tetsuya Kawae, \\ Chizuru IGUCHI and Yasuaki OKUMURA
}

\begin{abstract}
Horizontal distributions of wind over Lake Biwa have been measured almost simultaneously using three boats. Time changes in wind were also measured at several coastal points. These data, including AMeDAS and continuous records in Shiga Prefecture, were analyzed to find the characteristics of wind fields over and around Lake Biwa. Results show that the wind is not spatially uniform, and that the dominant strong northerly wind has a positive curl in the northern area of the lake and a negative curl in the south. This wind distribution is considered to be one of the most important maintenance mechanisms of the horizontal water circulation (gyres) often observed in Lake Biwa. This possibility is confirmed in part by numerical calculations with a simple two-layer circulation model.
\end{abstract}

Key words : wind, water circulation, Lake Biwa

\section{Introduction}

The existence of stable horizontal water circulation (gyres) during the season of thermal stratification in Lake Biwa has long been well known (ENDOH, 1986; ENDOH and OKLMuRA, 1993). The formation and maintenance mechanisms of these gyres, however, have not been so clear. Two possible mechanisms have been proposed ; one is the unequal heat capture due to bottom topography (OONISHI, 1975; OоKUBO et al., 1984); and another is wind stress curl over the lake (ENDOH, 1976). Water circulations in Lake Biwa driven by a spatially uniform wind have been studied by some numerical experiments using barotropic models (IMASATO et al., 1975 ; OONISHI and IMASATO, 1975) and twolayer models (KANARI, 1974; ENDOH, 1976). These studies clarified that the uniform wind developed mainly oscillatory flows such as surface seiches, internal waves, and topographic Rossby waves. On the other hand, SudA et al. (1926) inferred that the locally prevailing southeast wind in the warm season was crucial to gyre formation, and HIDAKA (1927) carried out laboratory experiments to confirm this mechanism using a non-rotating barotropic hydraulic model. ENDOH (1976), in numerical experiments on water circulation caused by wind stress curl using a two-layer model, demonstrated the possible formation and main tenance of long-lived gyres.

KODAMA (1965) collected a number of wind data and inferred some typical wind systems in Shiga including Lake Biwa. On the basis of continuous wind recording over the lake, EDAGAWA (1986) pointed out that the wind fields over Lake Biwa are considerably non-uniform in space. However, very little has been known about wind fields over Lake Biwa due to the difficulty of direct measurements of wind distribution. In this article, some results of wind observations over and around Lake Biwa are reported, and the possibility of gyre formation by wind stress curl is shown by a simple numerical model.

\section{Wind measurements}

Figure 1 shows locations of observation stations on and around Lake Biwa. We set six transverse lines in the North Basin at $5 \mathrm{~km}$ intervals, and arranged observation stations at 
$4.4 \mathrm{~km}$ intervals on each line. Three boats were employed, each covering two lines within two hours. Two boats were the R/Vs Kosei and the Seiryu of Shiga University, and another was a fisherman's boat, the latter two reaching cruising speeds up to 20 knots. At every station, wind speed and direction were measured for about $5 \mathrm{~min}$ at a height of about $2 \mathrm{~m}$ above the lake surface, using a handy-type anemometer, a vane and a magnetic compass. Three quasisimultaneous observations of wind on the whole lake were carried out beginning at 10:00, 12:00 and 14:00 each day. The positionings were made by GPS.

In addition to these wind measurements on the lake, time variations in wind speed and direction were measured at several coastal stations indicated by dark triangles in Figure 1. At every coastal station, winds were measured every $10 \mathrm{~min}$ from 10:00 to $16: 00$. The instru-

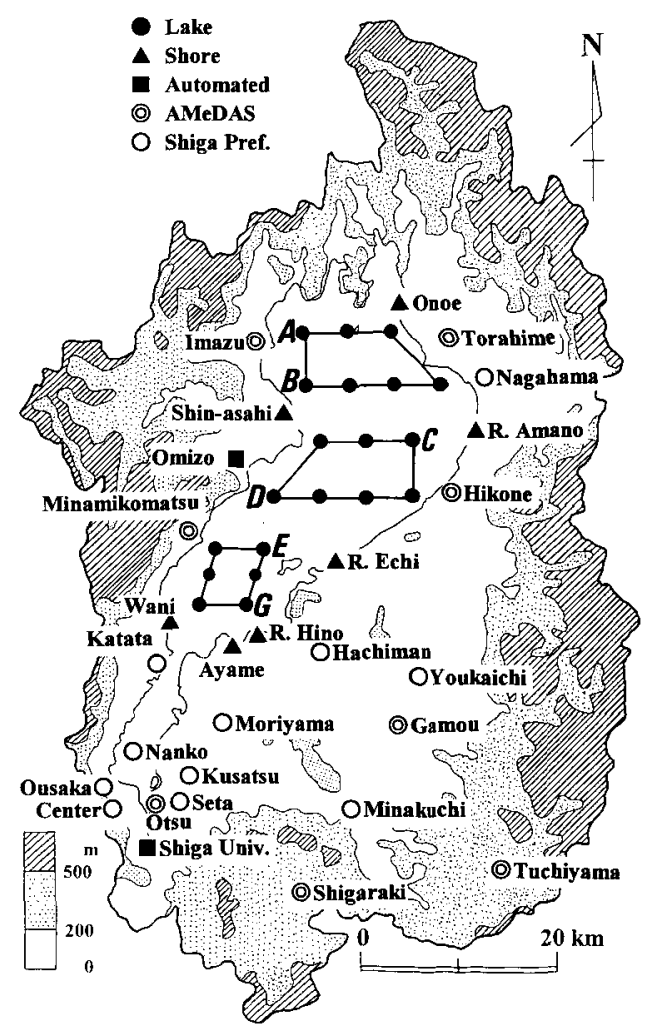

Fig. 1. Map of Shiga Prefecture showing locations of wind measurements on and around Lake Biwa. ments used were almost the same as those used on the boat. Anemometers were well calibrated before and after field measurements. Such observations on the lake and on the coast have been carried out 6 times since 1991. About 20 people were needed to complete each observation.

Continuous wind recorders were set at Shiga University and Omizo, so as to find the characteristics and frequencies of the dominant wind. We also analyzed wind data observed by AMeDAS and some meteorological stations operated by the Shiga Prefectural Government.

\section{Results}

Land and lake breeze is one of the most typical wind systems in Lake Biwa (EDAGAwa and NAKAJIMA, 1981). Figures 2 and 3 are examples of a lake breeze observed on the morning of 19 September 1992 and 29 May 1993, respectively. The wind is rather weak all over as well as around the lake. A divergence point can be seen at the center of the North Basin. The divergence is of the order of magnitude of $10^{-4} \cdot \mathrm{sec}^{-1}$. In the southern part of the North Basin, the wind is quite weak (Fig. 2) or north-east wind is prevailing down to the South Basin (Fig. 3).

Figure 4 shows the distribution of a fairly strong east wind observed on the afternoon of 29 May 1993. This east or southeast wind with a speed of 5 to $7 \mathrm{~m} \cdot \mathrm{sec}^{-1}$ blew in the northern area of the lake. This rather strong wind generated such big waves that the boat was unable to cruise the northernmost two lines. This wind system is frequently observed especially in the warm season (KODAMA, 1965), and is considered to be an excursion of a sea breeze from Ise Bay (EDAGAwA, 1992). It is quite obvious that this wind distribution has a positive (counterclockwise) curl in the north area of the lake. This was first pointed out by SUDA et al. (1926), and has been considered to be one of the formation mechanisms of a cyclonic gyre. ENDOH (1976) suggested by a numerical calculation that this strong easterly wind with a positive curl could induce a large cyclonic gyre. One question that should be answered in the near future is how frequent this wind type occurs. 


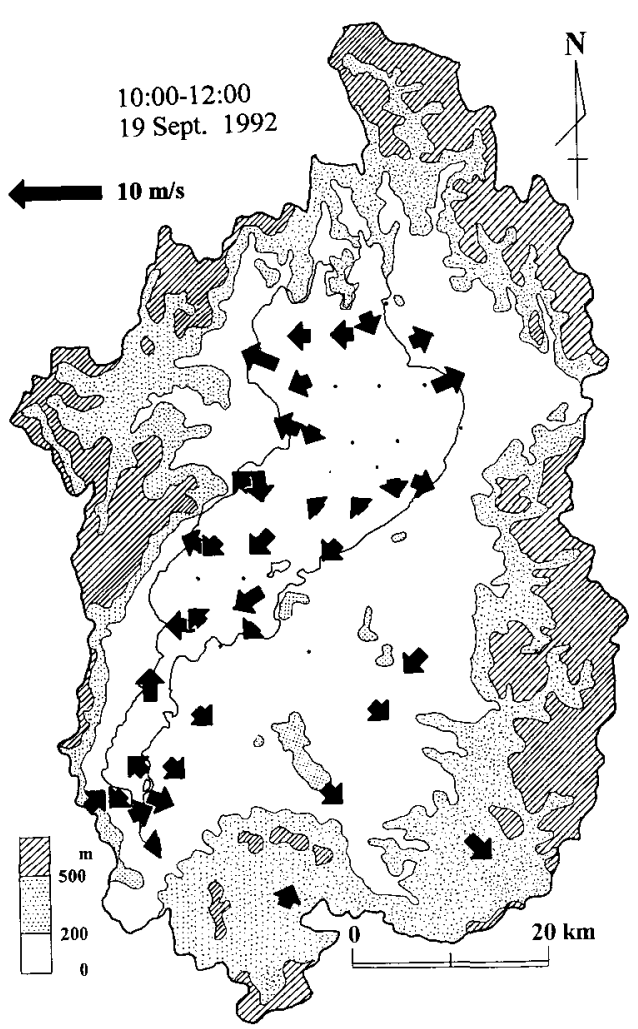

Fig. 2.An example of lake breeze distribution observed between 10:00-12:00 on 19 September, 1992.

The most dominant wind system in Lake Biwa is a strong northwest wind blowing mainly in the afternoon (EDAGAWA, 1986, 1992). Figures 5 and 6 show this wind field observed on 19 September 1992, and 14 October 1994, respectively. These two wind fields are very similar to each other and have the following three characteristic distributions. First, the wind is stronger in the northern than in the southern part. Second, wind direction gradually changes from $\mathrm{NW}$ in the northern part of the lake to $\mathrm{N}$ or $\mathrm{NE}$ in the southern part. Third, wind is somewhat stronger on the eastern than on the western side in the southern part of the North Basin (Fig. 5). This third characteristic of wind distribution was confirmed during BITEX'93 (Lake Biwa Transport Experiment) (ENDOH et al., 1994). As clearly shown in Fig. 6 and often observed previously (EDAGAWA, 1986), the wind is strongest in the middle of Lake Biwa.

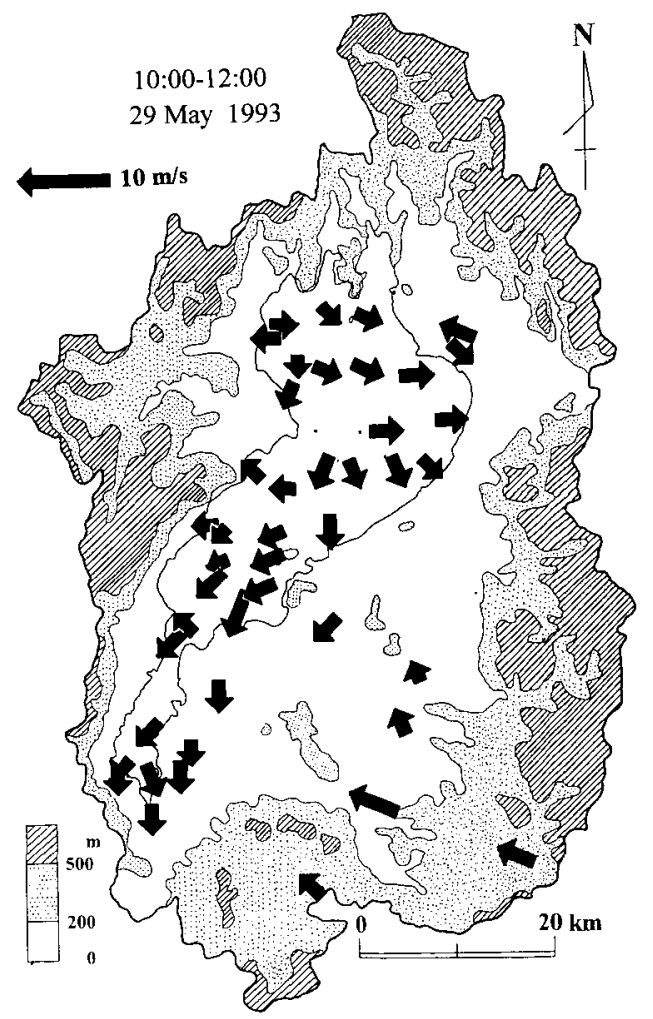

Fig. 3. Same as Fig. 2, except between 10:00-12:00 on 29 May, 1993.

This strong northerly wind system might be formed by the convergence of sea breeze from Wakasa Bay in the Japan Sea (KoDAMA, 1965; Edagawa, 1992). Therefore, this wind system is considered to be a local one since there is no strong wind around Shiga, as can be seen from Fig. 7 which shows a south wind (sea breeze) both at Kobe and Osaka. IтоH (1995) pointed out that such a local wind system depends on the formation of local high and low pressure caused by the extensive sea breeze system in the Kinki District.

Figure 8 shows seasonal changes of wind roses at eight AMeDAS stations in Shiga Prefecture obtained in 1991. In this figure, it is quite . evident that a northwest wind is dominant throughout the year, especially in the northern part of Shiga (Imazu, Torahime and Hikone). These frequent northerly winds are usually strong. It is also interesting that southerly 


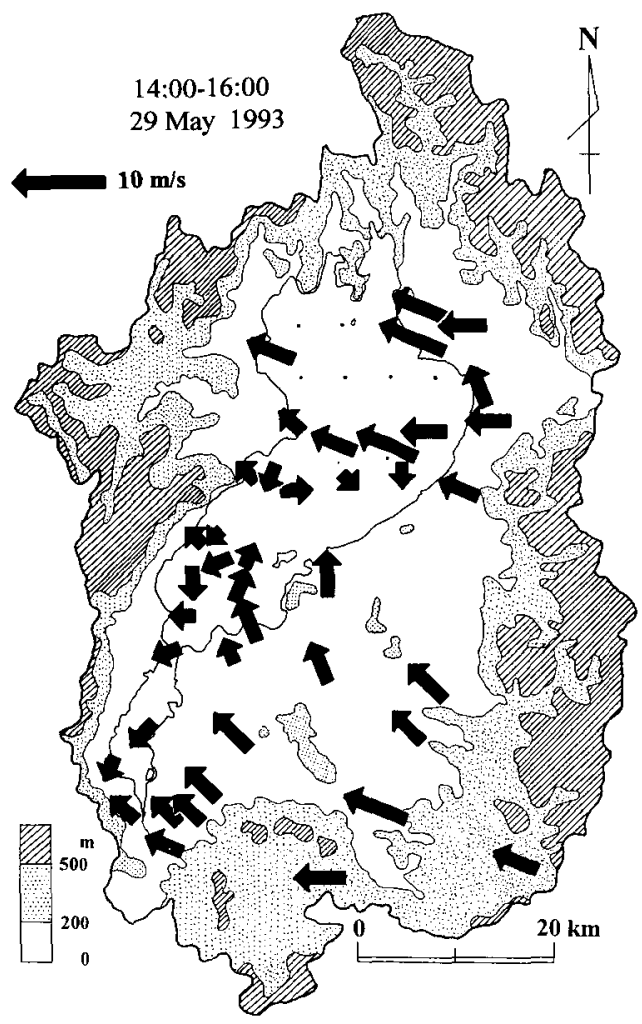

Fig. 4. Distribution of strong southeast wind observed between 14:00-16:00 on 29 May, 1993.

winds frequently occur at Torahime, Hikone, Gomou and Tsuchiyama in the warm season. This wind system might correspond to the southeast wind shown in Fig. 4.

\section{Numerical calculation of water circulation driven by observed wind fields}

Figure 9 shows the distribution of wind stress curl over Lake Biwa calculated from the wind field between 14:00-16:00 on 19 September 1992, as was already shown in Fig. 5. For this calculation, wind data were interpolated on $26 \times 63$ square grids at $1 \mathrm{~km}$ intervals by assuming that the effect of each observed station was inversely proportional to the distance. The interpolation was made using four observed stations. Data were then smoothed by medium weighted averaging. Wind stress $\boldsymbol{r}$ is obtained by $\boldsymbol{r}=\rho_{a} y_{a}{ }^{2}$ $|\boldsymbol{W}| \boldsymbol{W}$, where $\rho_{a}$ is the density of the air $(1.2 \times$ $10^{-3} \mathrm{gr} \cdot \mathrm{cm}^{-3}$ ), $\gamma_{a}^{2}$ the drag coefficient (taken to

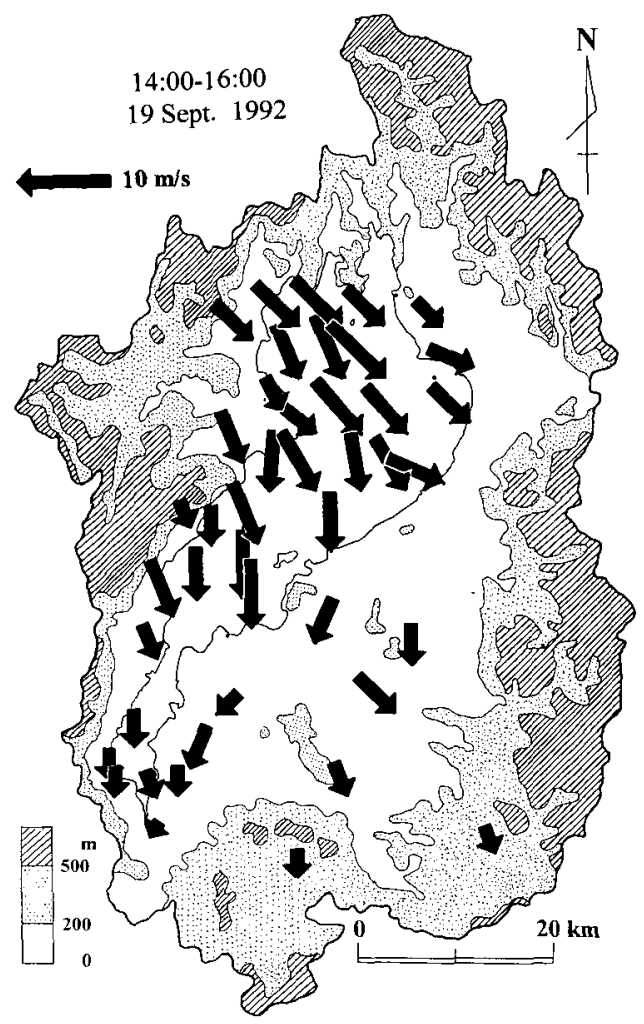

Fig. 5. Distribution of strong northwest wind observed between 14:00-16:00 on 19 September, 1992.

be $1.3 \times 10^{-3}$ after Kunishi, 1963), and $\boldsymbol{W}$ the wind vector. Wind stress curl was calculated at every grid point using $\nabla \times \boldsymbol{\tau}=\partial \tau_{y} / \partial \boldsymbol{x}-\partial \tau_{x} / \partial \boldsymbol{y}$, where $\left(\tau_{x}, \tau_{y}\right)$ are the east and north components of $\boldsymbol{r}$, respectively. In Fig. 9, it is quite clear that there is an intense positive (counterclockwise) curl of wind stress in the northern area of the lake, whereas a negative (clockwise) wind stress curl can be seen in the southern part.

Using this distribution of wind stress, the horizontal distribution and time variation in water circulation driven by the wind in Lake Biwa were examined using a linear two-layer circulation model developed by ENDOH (1976). This model contains a warm upper layer with a depth of $h_{1}$ and a cool lower layer with a depth of $h_{2}$. Under the assumptions of rigid lid and hydrostatic conditions, the fundamental equations are as follows: 


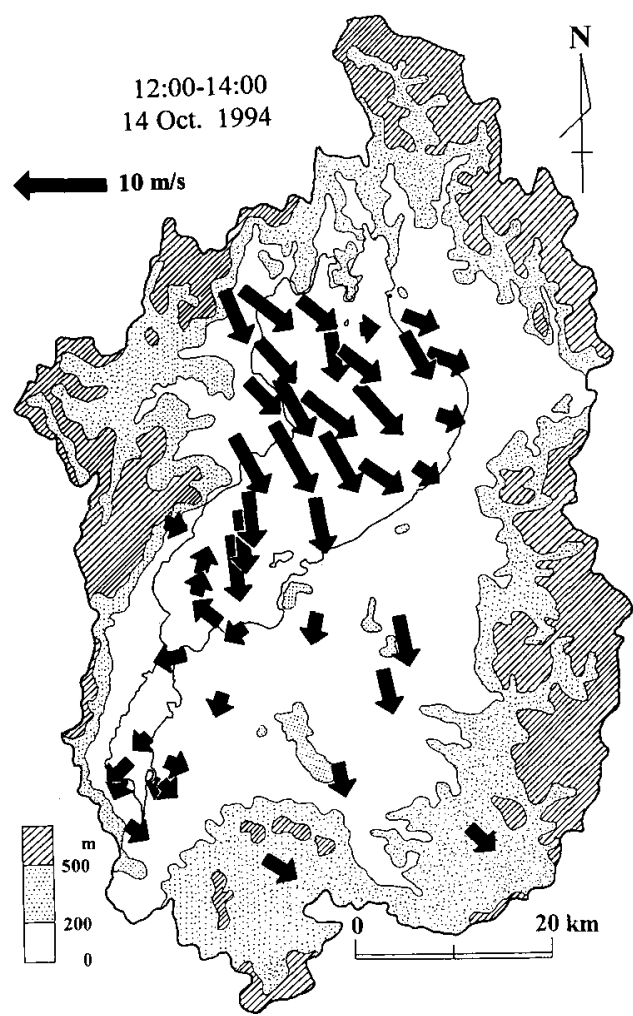

Fig. 6. Same as Fig. 5, except between 12:00-13:30 on 14 October, 1994.

$$
\begin{aligned}
& \partial u_{1} / \partial t-f v_{1}=-g \partial \xi_{1} / \partial x+\mu \nabla^{2} u_{1}+\tau_{x} / h_{1} \\
& \partial v_{1} / \partial t+f u_{1}=-g \partial \xi_{1} / \partial y+\mu \nabla^{2} v_{1}+\tau_{y} / h_{1} \\
& \partial\left(h_{1} u_{1}+h_{2} u_{2}\right) / \partial x+\partial\left(h_{1} v_{1}+h_{2} v_{2}\right) / \partial y=0 \\
& \partial u_{2} / \partial t-f v_{2}= \\
& \quad-g \partial \xi_{1} / \partial x-g\left(\rho_{2}-\rho_{1}\right) \rho_{2}^{-1} \cdot \partial \xi_{2} / \partial x+\mu \nabla^{2} u_{2} \\
& \partial v_{2} / \partial t+f u_{2}= \\
& \quad-g \partial \xi_{1} / \partial y-g\left(\rho_{2}-\rho_{1}\right) \rho_{2}^{-1} \cdot \partial \xi_{2} / \partial y+\mu \nabla^{2} v_{2} \\
& \partial \xi_{2} / \partial t=-\partial\left(h_{2} u_{2}\right) / \partial x-\partial\left(h_{2} v_{2}\right) / \partial y
\end{aligned}
$$

where $\nabla^{2}=\partial^{2} / \partial x^{2}+\partial^{2} / \partial y^{2}$. Here, $\left(u_{1}, v_{1}\right)$ and $\left(u_{2}, v_{2}\right)$ are current velocities in the upper and lower layers, $\rho_{1}$ and $\rho_{2}$ the water density in the upper and lower layers, $\xi_{1}$ and $\xi_{2}$ are elevations of the lake surface and the interface between two layers, and $f, g$ and $\mu$ the Coriolis parameter, acceleration due to gravity and horizontal eddy viscosity, respectively.

The calculations were made using a model lake basin with $1-\mathrm{km}$ square grids including the lake geometry and bottom topography. Parameters were set at $\boldsymbol{h}_{1}=15 \mathrm{~m}$ and $\left(\rho_{2}-\rho_{1}\right) / \rho_{2}=$

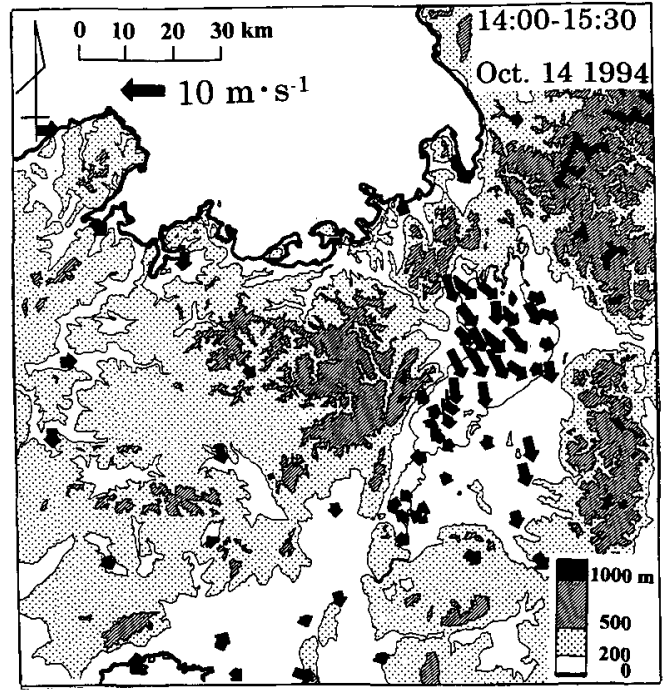

Fig. 7. Wind distribution in Kinki District for the case of Fig. 6.

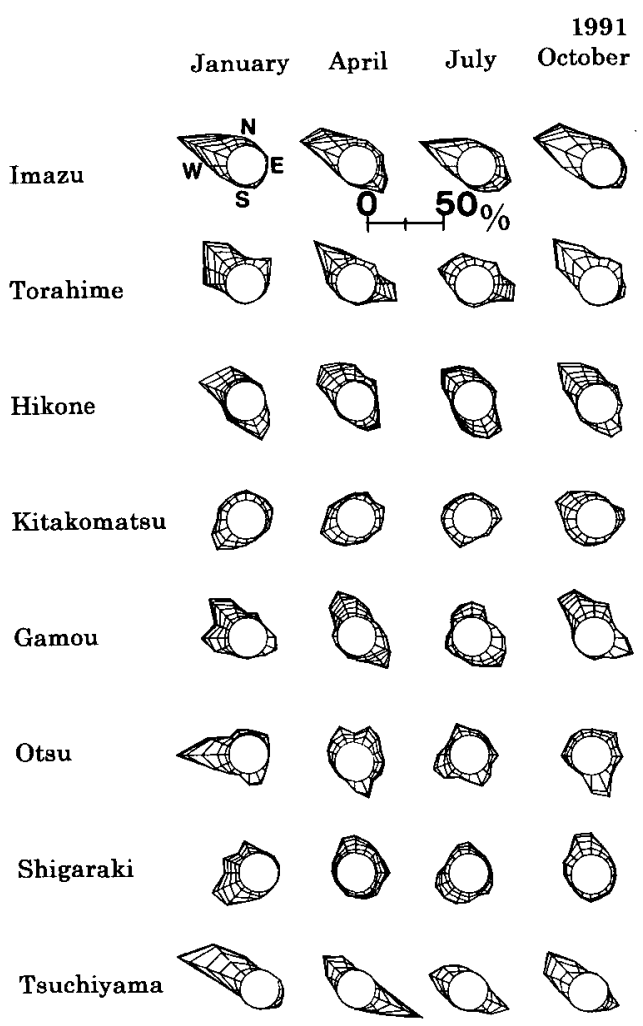

Fig. 8. Seasonal changes of wind roses in 1991 at eight AMeDAS stations in Shiga Prefecture. Frequency of each 16 of wind directions is expressed together with the wind speed at $1 \mathrm{~m} \cdot \mathrm{sec}^{-1}$ interval. 
$2.5 \times 10^{-3}$ on the basis of the observed values in September 1992. Horizontal eddy viscosity $\mu$ was assumed to be $10^{3}$ to $10^{5} \mathrm{~cm}^{2} \cdot \mathrm{sec}^{-1}$, but was not so sensitive to the result. Only the case of $\mu=10^{4} \mathrm{~cm}^{2} \cdot \mathrm{sec}^{-1}$ is shown here. The effects of stresses at the lake bottom and the interface were also examined, but these were found to exert little influence on the results. Observed wind stress was suddenly imposed on the noflow initial condition $(t=0)$. Wind is assumed to blow continuously for $18 \mathrm{hr}$, maintaining the spatial distribution shown in Figure 5. This assumption was based upon the AMeDAS wind data which showed that the northerly wind had blown continuously for about $18 \mathrm{hr}$ while

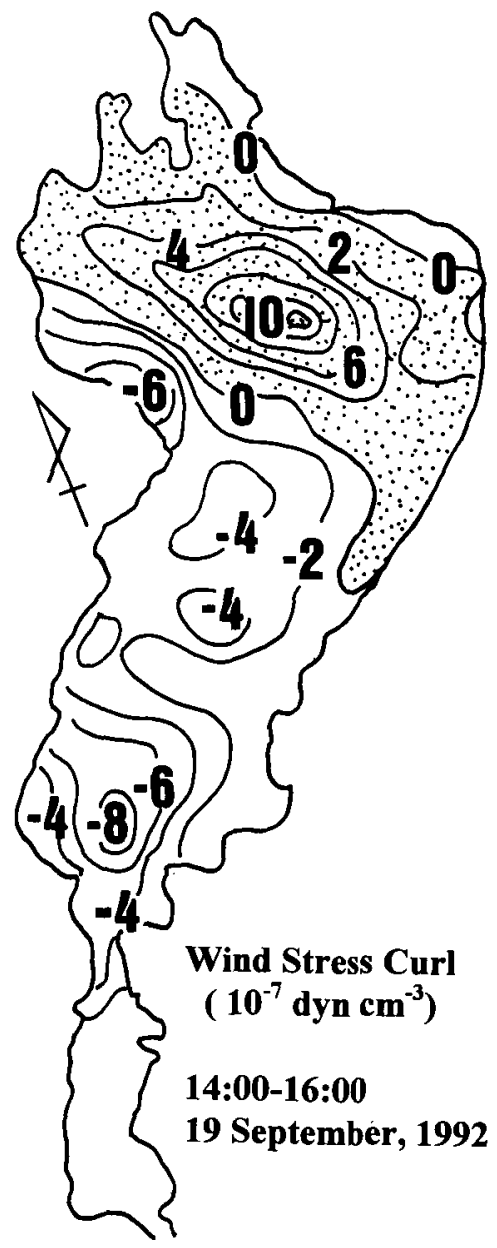

Fig. 9. Wind stress curl over Lake Biwa calculated from the wind field observed between 14:0016:00 on 19 September, 1992 (Fig. 5). maintaining an almost steady wind speed and direction. Horizontal distributions and time variations in currents in the two layers $\left(u_{1}, v_{1}\right.$, $u_{2}, v_{2}$ ) and the interface elevation $\xi_{2}$ were calculated every $15 \mathrm{~min}$. The surface elevation $\xi_{1}$ did not need to be explicitly calculated because of using a well designed scheme with the stream function for depth-integrated volume transport and the boundary value problem.

Figure 10 shows the distributions of vertically integrated volume transport (a), and current vectors in the upper layer (b) and the lower layer (c), $24 \mathrm{hr}$ after the wind stopped. In Fig. 10 (a), it is quite evident that two large gyres were formed in the lake : a counter-clockwise circulation in the northern part and a clockwise one in the south. This circulation pattern is also visible in the upper layer (Fig. 10b) with a current speed of about $10 \mathrm{~cm} \cdot \mathrm{sec}^{-1}$. In the lower layer, however, the current is very weak and shows no circulating current pattern.

Time variations in calculated current vectors in the upper layer are shown in Fig. 11. In this figure, current vectors at six grid points are plotted every $15 \mathrm{~min}$ for about 10 days. Wind was stopped at $18 \mathrm{~h}$ of the first day which is shown by a vertical dashed line. It is quite clear that a large amplitude of current fluctuation exists at every point. Spectral analysis by FFT reveals that the most dominant fluctuation is caused by the slowest internal Kelvin wave with a period of $51 \mathrm{hr}$. In the northern area (points $\mathrm{A}, \mathrm{B}$ and $\mathrm{C}$ ), a current variation with a period of $11 \mathrm{hr}$ is developed. This periodic current fluctuation is considered to be an internal Poincaré wave as found out by the continuous current measurements (ENDOH and OKUMURA, 1989).

Note that Fig. 11 shows the constant current components at many grid points in spite of a large amplitude of time variation. For example, the northward currents are maintained for more than a week at points $A, B, D$ and $G$, though they are gradually decreased by the horizontal viscosity. Such a result of a non-zero averaged current driven by the wind stress curl is much different from that obtained by a calculation with uniform wind (ENDOH, 1976).

It is quite interesting that the current pattern 

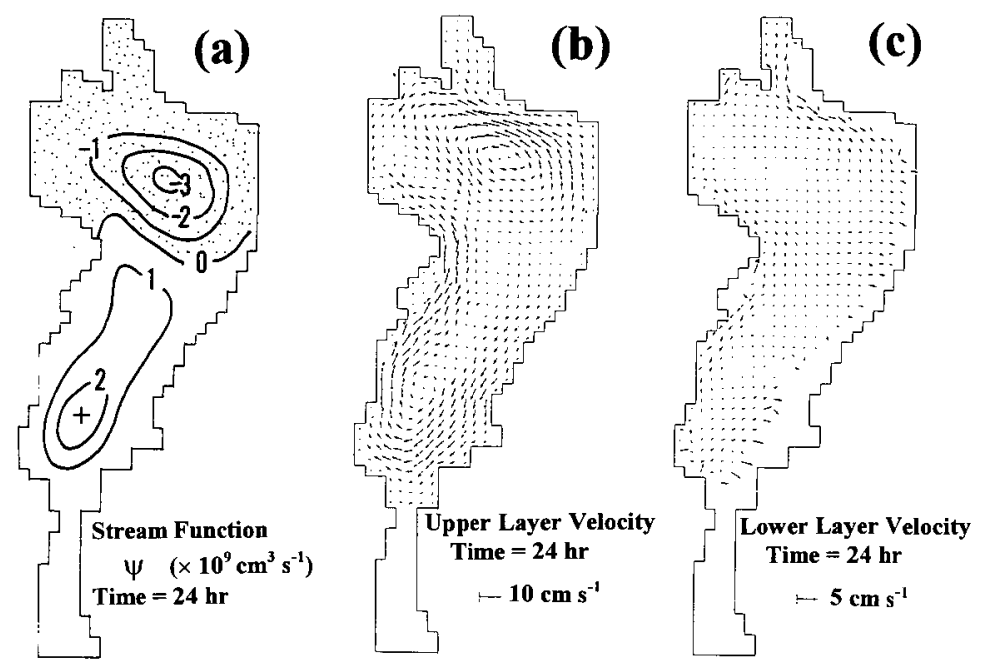

Fig. 10. Results of calculation by two-layer model: vertically integrated volume transport (a), current velocity in the upper layer (b), and current velocity in the lower layer (c), at $t=42$ hr (one day after the wind has stopped).

obtained by the numerical calculation (Fig. 10) is similar to that observed by current meters and buoy tracking (ENDOH and OKUMURA, 1993). Many theories have been proposed to explain the formation of a cyclonic (counterclockwise) gyre in lakes; for example, the thermal bar (BENNET, 1971), the Stokes drift (WUNSCH, 1973), heat redistribution from coastal upwelling (CSANADY, 1977), and absence of heat flux through the bottom boundary (SCHWAB et al., 1995). However, very little has been proposed regarding the mechanism involved the formation and maintenance of an anti-cyclonic (clockwise) gyre. OоKuBo et al. (1984) showed the formation of the Second Gyre in Lake Biwa as well as the First Gyre from a series of physical laboratory experiments. The Second Gyre obtained by OOKUBO et al. (1984), however, lies somewhat to the north and is weak compared with that observed in Lake Biwa. The clockwise circulation in Fig. 10 is located south of the observed one, but has a reasonable current speed. ENDOH et al. (1994) found that a clockwise circulation dominates in the southern half of the North Basin and that it is mainly caused by the northerly wind with a negative curl in summer. Therefore, a long ellipse-shaped clockwise circulation as in Fig. 10 can be formed by the north wind in the southern half of the North Basin. It is still unknown whether one clockwise gyre or double gyres can be driven. This question should be answered by making comprehensive observations.

In Fig. 10, a counterclockwise gyre (the First Gyre) in the northern part of the lake is also a little different from the observed one. According to studies on thermally driven gyres in Lake Biwa (OONISHI, 1975 ; OоKubo et al., 1984), it can be deduced that the maximum energy content should occur in July when the buoyancy flux is at its maximum. On the other hand, the First Gyre reaches its maximum energy in September and is maintained almost until November (ENDOH, 1986). Thus, the First Gyre in Lake Biwa is considered to develop mainly by thermal effects in spring, and is maintained by the effects of heating, wind stress curl and other mechanisms noted above. In autumn, when the heating effect declines, the First Gyre should remain energized by the persisting wind stress curl.

\section{Acknowledgments}

We express our sincere thanks to Prof. I. Okamoto, Prof. H. Edagawa and Dr. Y. Oonishi for their encouragement and useful discussion. 


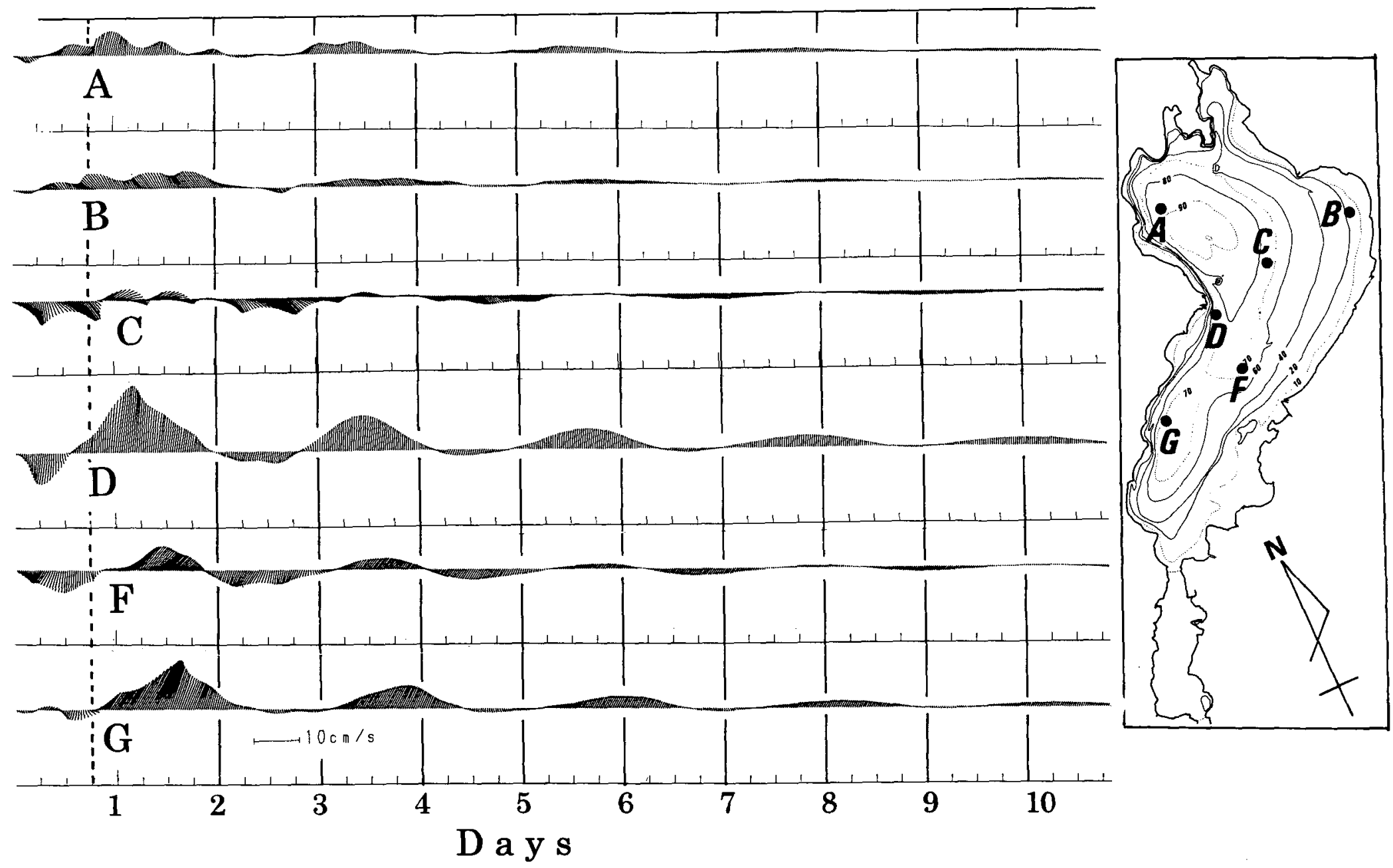

Fig. 11. Time variations in calculated current vectors in the upper layer at several points. Upward vector indicates the northward current. 
We also thank Hikone Meteorological Observatory and Shiga Prefectural Institute of Public Health and Environmental Science for supplying us valuable wind data. Thanks are extended to Messrs. H. Omura, T. Murakami, M. Ebina, H. TAKEdA and Mrs. C. OgaWA for their help and suggestions throughout this study, and to many students of Shiga University and Osaka Electro-Communication University for their help in field observations.

\section{摘要}

\section{びわ湖上の風系と半れが湖流に与える影響}

びわ湖上において 3 隻の船を用いて同時性の高 い風の分布の観測を行った。また，湖岸の数ヶ所 でも同時観測を実施した。これらのデータとアメ ダスや滋賀県の風の観測記録を用いて，びわ湖お よび滋賀県の風の特徵を調べた。その結果, 風は 決して一様ではなく,びわ湖で卓越する北西系の 強風は湖の北部では反時計回りの渦度を, 南部で は時計回りの渦度をもつことがわかった。このよ うな風の分布は, びわ湖の水平循環流（環流）の 形成機構として重要であり,線型2層モデルを用い た数值計算によって環流形成の可能性が示され た。

\section{References}

BennetT, J. R. (1971) : Thermally driven lake currents during spring and fall transition period. Proc. Conf. Great Lakes Res. 14 : 535-544.

CSAnAdy, G. T. (1977): On the mean circulation of large lakes. Proc. Natl. Acad. Sci. USA, 74 : 2204-2208.

EDAGAWA, H. (1986) : On the climate of Lake Biwa, western Japan. Geogr. Rev. Jpn. 59-10:589605 (in Japanese with English summary).

EDAGaWA, H. (1992): On the local winds developing toward evening in the northern part of the Lake Biwa Basin, western Japan. Geogr. Rev. Jpn. 65A-10:735-746 (in Japanese with English summary).

Edagawa, H. and C. Nakajima (1981) : A study of the land and lake breeze in the Lake Biwa basin. Geogr. Rev. Jpn. 54-10: 545-554 (in Japanese with English Summary).

ENDOH, S. (1976) : Study on the water circulation in Lake Biwa. M. S. thesis, Kyoto Univ. (in Japanese).

ENDOH, S. (1986) : Diagnostic study on the vertical circulation and the maintenance mechanisms of the cyclonic gyre in Lake Biwa. J. Geophys. Res., 91C1: 869-876.

ENDOH, S. and Y. OKumura (1989): Continuous current measurements in Lake Biwa (II). Jpn. J. Limnol., $50: 341-350$ (in Japanese with English Abstract).

ENDOH, S. and Y. OKUMURA (1993) : Gyre system in Lake Biwa derived from recent current measurements. Jpn. J. Limnol., 54 : 191-197.

Endoh, S., K. Tsukamoto, K. Sagi, M. Konagaya, Y. OKUMURA and I. Окамото (1994): Water circulation in the BITEX Area. BITEX Symposium/Workshop Short Papers: 116-122.

HIDAKA, K. (1927) : Model experiment on the lake currents in the surface layer of Lake Biwa. Bull. Kobe Marine Obs., 13: 1-4 (in Japanese).

Imasato, N., S. Kanari and H. Kunishi (1975): Study on the currents in Lake Biwa (I) barotropic circular currents induced by the uniform wind. J. Oceanogr. Soc. Japan, 31: 15-24.

IroH, H. (1995): Numerical experiments on the extended sea breeze in the Kinki District. Tenki, 42-1: 17-27 (in Japanese).

KANARI, S. (1974) : On the study of numerical experiments of two layer Lake Biwa. Jpn. J. Limnol., $35: 1-17$.

Kodama R. (1965) : On the wind system in Shiga Prefecture. J. Meteor. Res., 18:49-52 (in Japanese).

Kunishi, H. (1963) : An experimental study on the generation of wind wave. Bull. Disast. Prev. Res. Inst., Kyoto Univ., $6: 1-41$.

Ookubo, K., Y. Muramoto, Y. Oonishi and M. Kumagai (1984): Laboratory experiments on thermally induced currents in Lake Biwa. Bull., Disast. Prev. Res. Inst., Kyoto Univ., 34 : 19-54.

OoNishi, Y. (1975) : Development of current induced by the topographic heat accumulation (I). J. Oceanogr. Soc. Japan, 31: 243-254.

OONISHI, Y. and N. Imasato (1975) : Study on the currents in Lake Biwa (II) barotropic responses to the uniform wind of a finite duration. J. Oceanogr. Soc. Japan, 31: 53-60.

Schwab, D. J., W. P. O'Connor and G. L. Mellor (1995): On the net cyclonic circulation in large stratified lakes. J. Phys. Oceanogr., 25 : 15161520.

Suda, K., K. Seki, J. Ishil, S. Takatani and S. MizuUchi (1926): The report of limnological observation in Lake Biwa-ko (I). Bull. Kobe Marine Obs., 8: 1-103. (in Japanese)

Wunsch, C. (1973): On mean drift in large lakes. Limnol. Oceanogr., $18:$ 793-795. 
（著者：遠藤修一・渡邊美和・永田大樹 - 丸尾文仁

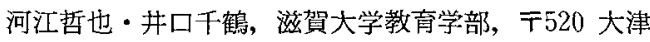
市平津 2-5-1; 奥村康昭, 大阪電気通信大学工学部, T575 四条畷市清潼1130-70: Shuichi ENDOH, Miwa Watanabe, Hiroki Nagata, Fumihito Maruo, Tetsuya KaWAE and Chizuru IGUCHI, Department of
Earth Science, Shiga University, 2-5-1 Hiratsu, Otsu 520; Yasuaki OкuмuRa, Faculty of Engineering, Osaka Electro-Communication University, Kiyotaki, Shijonawate, Osaka 575)

Received : 13 May 1995

Accepted : 6 September 1995 